\title{
Exploring Inclusion in Secondary Schools: A Study on Dhaka City
}

\author{
Nazmun Nahar Chaitee ${ }^{1 a^{*}}$, Biplob Mallick ${ }^{2 b}$, Md. Shamsul Arefin ${ }^{1 c}$ \& Fatema Begum Popy ${ }^{3 \mathrm{~d}}$ \\ 1Lecturer, Department of Educational Administration, ${ }^{2}$ Associate Professor, Department of Education, ${ }^{3}$ Lecturer, \\ Department of Education, Faculty of Education sciences, Noakhali Science and Technology University, Noakhali- \\ 3814, Bangladesh \\ a chaiteenaaz@gmail.com, b biplob@nstu.edu.bd, c arefindup@gmail.com,dpop_du16@yahoo.com \\ Corresponding Author : chaiteenaaz@gmail.com | Phone : 01571775811
}

\begin{abstract}
This paper presents findings of a mixed methods research which is mainly exploratory research by nature. The primary data have been collected from 180 students and 60 teachers by questionnaires, classroom observation and FGD. To analysis the data a descriptive triangulation approach is used. The Major purpose of this study is to present the practice of inclusive education on inclusive schooling in Dhaka city and other vulnerability discourses that elevated utmost challenges for survival of students with Disabilities (PWDs), disadvantage, gender discrimination during study time. The study findings explore multiple factors poses a threat to inclusion, as Bangladesh is considered one of the most growing concern countries in the world about inclusion. The study reveals that there is gender equity and empty gender discrimination in Dhaka city but still there is unpleasant proportion between student and teacher ratio. Although the lack of enough facilities, schools are welcoming different categories of students in their classroom while teachers are not always prepared to support students for ensuring quality education together with special need child. Though the different initiatives have been taken to train the teachers, which is a must for achieving goals but there is a lack of trained teachers in school to nurture the special need children whereas unified curriculum has been used with ICT teaching-learning materials. Making creative question is one of the most highly encouraging reforms in our country and whenever students take it positively but teachers either have a little idea or dislike the process. In this circumstances it is expected that the findings would influence policies for ensuring inclusive intervention of preparedness and rehabilitation.
\end{abstract}

Keywords: Secondary Education; Inclusion; Inclusive Education; Educational Reforms ;

\section{Introduction}

Bangladesh has made remarkable progress in increasing education access over the past two decades especially for girls and inclusive education. Although the significant developments has been happened in education, substantial inequalities in educational attainment remain even though equity, equality, quality and inclusion in education is a central government objective (UNESCO, 2009). According to Ministry of Education (MoE, 2004) our education system of Bangladesh has gone through many changes. All the changes were applied as an initiative to ensure better educational scenario in Bangladesh. At the same time the government has undertaken a number of policy reform initiatives to improve the quality of secondary education (Ahsan \& Burnip, 2007). Al-Samarrai, (2007) also stated that GoB has explored the policy reform in junior secondary education in Bangladesh from 1993 to 2019 for ensuring quality education which has intended to identify the success of the education reforms in junior secondary level. Inclusive Education (IE) is one of those initiatives which has been considered as an educational reform that aims to reduce the barriers for welcoming the all children into regular education, irrespective of their diversity and backgrounds (UNESCO, 1994). The Education Policy 2010 recognized inclusive education as a viable strategy to ensure education for all learners and emphasis was given to ensure education right of children with disabilities (MoE, 2010). The proposed Draft Education Act 2013 (MoE, 2013) also articulated equal right of all children into education and mentioned that inclusive education could be a strategy to eradicate inequalities into education. In continuation with these initiatives, Bangladesh also enacted a legislation named as the Rights of the persons with Disabilities and their Protection Act, 2013 (MSW, 2013) to ensure different rights including enrollment into education. Inclusion of children from diverse backgrounds (i.e., children with disabilities and children from socially disadvantaged backgrounds) in the mainstream regular education is focused not only in Bangladesh but also it is a global trend in recent days to ensure rights to 
education for all (UNESCO, 2009). Moreover, the constitution of Bangladesh ensures that all citizens of the country have equal right to enjoy their dignity, fundamental human rights and have social equality. Along with these issues, the study aimed to assess gender equity and equality in secondary schools for identifying those problems which are considered as barriers to ensuring educational reforms.

\section{Problem Statements}

The education system of Bangladesh is continually undergoing reforms in order to meet the current and future needs and challenges of the socio-economic developments of the country. In that course of change, secondary education of Bangladesh has achieved a number of positive developments and has made significant progress like enrollment of more young people especially for girls in secondary education (Asian Development Bank, 2010), reduce gender inequality, increase number of schools and teachers, make revision of curriculum and introduce unified curriculum (Andaleeb, 2009). Besides the stated initiatives, several training programs have been organized to teacher together with school managing committee for effective inclusion of children regardless their diversities in schools all over Bangladesh. Even so many remarkable achievements, declining quality in secondary education system, which is reflected in public examination results, fearfulness of exams like JSC, PSC particularly for especial children because schools do not have much facilities for its students remain a major concern (Campaign for Popular Education, 2005). On the other hand, still a lot of children are out of schools or dropped out from schools in Bangladesh and around $53 \%$ of them are children with disabilities (Ahsan, 2013). Besides the above stated problems teachers feel less confident in including children with disabilities in their schools (Forlin et. al, 2009). Moreover, the children's family income, status and their background have been treated as challenges to take admission in schools which is bad indicator for inclusive education.

Among many other challenges negative attitudes, limited resources, traditional curriculum framework and teaching- learning strategies, ill- preparation of school teachers are some of the major factors that are hindering equal right to education through implementing the values of inclusive education around the world including Bangladesh (Ahmmed et.al, 2012; Ahsan, Sharma \& Deppeler, 2012, 2013; Avramidis \& Norwitch, 2002). On the other hand, gender disparity and inequality in secondary schools are also considered as problems that makes barriers ensuring inclusion friendly environment in schools. However, this study intends to explore the policies related to inclusion education in junior secondary education and identify the barriers which hinders the successful integration of IE in schools. It is also expected that the findings of this study would influence the policies for ensuring inclusive intervention of preparedness and rehabilitation. It will support the concerned development actors and planners to formulate need-based plan and can initiates appropriate programs for the mitigation of loss for the most vulnerable section of education.

\section{Research Objectives}

The main objective of this study is to find out the ways of ensuring inclusion in secondary education of Dhaka city in Bangladesh. There are also some additional objectives to fulfill the main objective of this study. Those are stated below:

- find out the barriers of implementing quality education through inclusive friendly environment.

- to explore the existing infrastructural facilities of junior secondary schools in Bangladesh

- to explore the reformed policy within junior secondary education in Bangladesh

- to point out the ways of ensuring inclusion in secondary education of Bangladesh

\section{Materials and Methods}

This study follows mixed and exploratory research by nature based on primary data which have been collected through questionnaires, classroom observation and FGD.

\subsection{Population and Sample}

All the students of junior secondary schools in Bangladesh are the population of this study. The target population of this study comprised of those school's students and teachers which have been accepted educational reforms and have been guided by the rules. 


\subsection{Sample design and Sample size}

For this study, six schools from Dhaka city have been selected purposively. There are 30 students of grade vi-viii and 10 teachers from each school selected as sample. Therefore, all together $180(30 \times 6)$ students and $60(10 \times 6)$ teachers nominated as sample for this study. They are selected purposively and, in an effort, to represent the overall teachers and students population. However, the samples are chosen randomly from the study area. Similarly, 18 ( 3 X 6) classrooms have been observed by observation checklist. The questionnaire survey and FGD have been administered to collect primary data. On the other hand, a descriptive triangulation approach is used to analyze the data obtained from questionnaire survey and classroom observation. Triangulation of quantitative and qualitative data increase the credibility and validity of this study. SPSS software is employed for statistical analysis of the quantitative data. Different themes are identified, and data are analyzed under each theme. Simple percentages of respondents against the supplied evidence are computed for questionnaires and classroom observation. The following figure insight about sample size selected in this study.

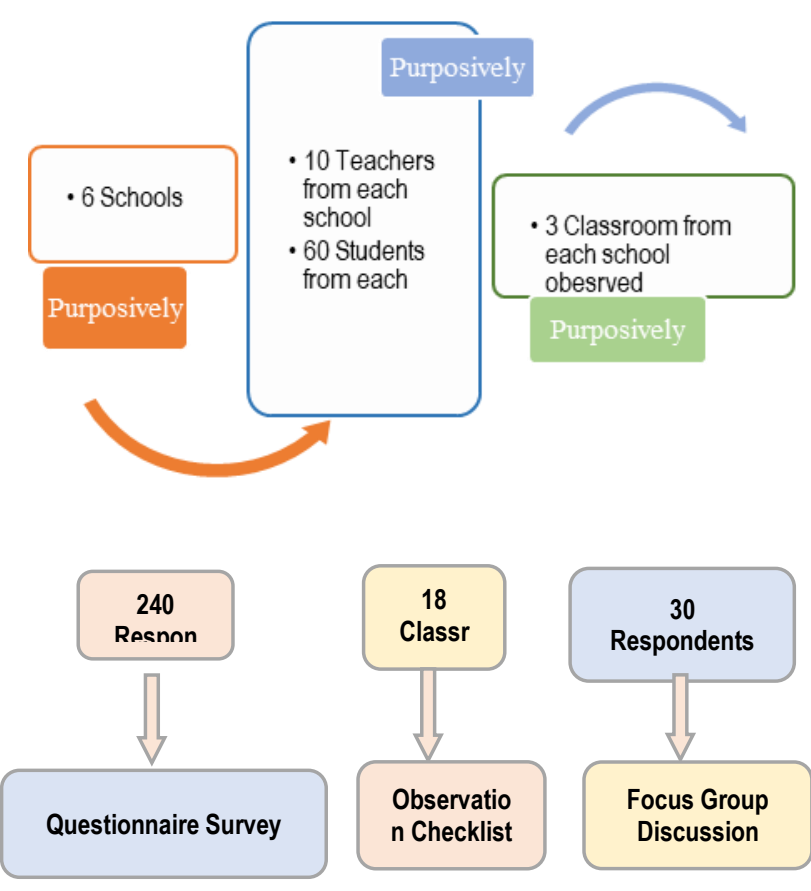

Figure: 1 Sample Size

\subsection{Data Analysis and Discussion}

The analysis of primary data is very important to relate them with secondary data in order to attain the aim and objectives of this study. However, the presentation of collected primary data in this study helps to understand the existing situation of inclusion in junior secondary education in Dhaka city. There are total 240 respondents participated in this data collection process. The results of this study are presented below.

Table-1: Students ratio (boys : girls) in schools

\begin{tabular}{ccccccc}
\hline Class & School 1 & School 2 & School 3 & School 4 & School 5 & School 6 \\
\hline 6 (Boys:Girls) & $21: 20$ & $15: 21$ & $23: 19$ & $25: 26$ & $29: 26$ & $27: 23$ \\
\hline 7 (Boys:Girls) & $20: 22$ & $22: 20$ & $21: 22$ & $26: 24$ & $23: 25$ & $28: 24$ \\
\hline 8 (Boys:Girls) & $25: 21$ & $19: 21$ & $20: 22$ & $25: 25$ & $23: 21$ & $28: 26$ \\
\hline
\end{tabular}

Table-1 represents the ratio between boys and girls and it confirms that the boys and girls are almost equal in junior secondary schools. The ratio provides a good insights about enrollment of children in schools regarding the ratio male and female (51: 49) in Bangladesh. Data tells that the access of children in schools are equal addressing gender equity and equality which is a very important milestone for ensuring inclusive education. 
Table-2: Teacher and student ratio in schools

\begin{tabular}{ccccccc}
\hline Grade & School 1 & School 2 & School 3 & School 4 & School 5 & School 6 \\
\hline VI(Teacher: Student) & $1: 41$ & $1: 46$ & $1: 42$ & $1: 51$ & $1: 55$ & $1: 50$ \\
\hline VII (Teacher: Student) & $1: 42$ & $1: 42$ & $1: 43$ & $1: 50$ & $1: 48$ & $1: 52$ \\
& & & & & & $1: 41$ \\
\hline VIII(Teacher: Student) & $1: 46$ & $1: 40$ & $1: 42$ & $1: 50$ & & $1: 54$ \\
& & & & & & \\
\hline
\end{tabular}

Table-2 shows the ratio of teacher and student covered in this study which does not show a healthy situation for inclusive learning friendly environment. However, the quality education requires a proper teacher and student ratio whereby teachers can play more effective role. On the other hand, the successful integration of inclusive education in schools needs a balanced teacher student ratio to reduce the teaching load of teachers.

Table-3: Social background of students

\begin{tabular}{cccc}
\hline Variables & $\mathrm{f}$ & $\%$ \\
\hline High & 40 & 22 \\
\hline Medium & 112 & 62 \\
\hline Low & 28 & 16 \\
\hline Total & 180 & 100 \\
\hline
\end{tabular}

Table-3 reflects that the students with different economic background have enrolled in schools. According to the results, most of the students are from middle $(62 \%)$ and low $(16 \%)$ income family while high economic background students are found $22 \%$ in this study. In regards with economic background, one of the FGD participants exposed-

"I come from a middle-class family, my father is a banker and mother is a housewife. One of my best friends is Navid, his father is a teacher. Like Navid, most of my classmates belong to middle class status. On the other hand, Borsha is one of our classmate who belongs to an upper-upper class family and her father is an old town's rich businessman. Conversely, a few of classmates of mine also belong to lower middle-class family."

Table-4: Students ratio of disabilities, ethnic minority with general students

\begin{tabular}{|c|c|c|c|c|c|c|}
\hline $\begin{array}{c}\text { Grade } \\
\text { (children with disabilities, Ethnic } \\
\text { minority: } \\
\begin{array}{c}\text { Normal } \\
\text { Students) }\end{array}\end{array}$ & School 1 & School 2 & School 3 & School 4 & School 5 & School 6 \\
\hline Grade - VI & $1: 40$ & $1: 46$ & $2: 42$ & $2: 51$ & $1: 55$ & $0: 50$ \\
\hline Grade -VII & $0: 42$ & $3: 41$ & $2: 41$ & $1: 50$ & $0: 48$ & $1: 52$ \\
\hline Grade VIII & $2: 46$ & $1: 39$ & $0: 42$ & $0: 50$ & $1: 41$ & $1: 54$ \\
\hline
\end{tabular}

Table-4 explains the ratio between disabilities and ethnic minority with general students. The results indicate that there is a few students found with disabilities and ethnic minority in regular classroom whereas some of classes have been identified with no disabilities and ethnic minorities of students. Despite have a little access of students with disable and ethnic group of students in schools regarding the ratio of enrollment of students, the limited inclusion of difficulty able child in school is one of the major concern for establishing equal right to education.

Table-5: Level of discrimination bases on gender religion, social status and merit

\begin{tabular}{|c|c|c|}
\hline Variables & f & $\%$ \\
\hline Yes & 28 & 16 \\
\hline No & 136 & 75 \\
\hline $\begin{array}{c}\text { No } \\
\text { respond }\end{array}$ & 16 & 9 \\
\hline Total & 180 & 100 \\
\hline & & \\
\hline
\end{tabular}


Table- 5 demonstrates what extent the teachers possess differentiate among the studen ts regarding their religion, gender, social status and merit position. The results indicate relatively positive image of teachers because most of the students $(\mathrm{f}=136 ; \%$ 75) disclose that they are not mistreated by their religion, gender, social status and merit position. However, $16 \%$ students expose that they feel discrimination because of their religion, gender, social status and merit whereas $9 \%$ of students are neutral about the topic. P2FGD1 said-

"Teachers do not discriminate students by their social status, religion but sometimes they feel their teachers prefer meritorious students more and being biased for that."

Table-6: Facilities for Inclusive Education in Schools
\begin{tabular}{|c|c|c|c|}
\hline \multicolumn{2}{|c|}{ Variables } & $\mathrm{f}$ & $\%$ \\
\hline Having special facility & Yes & 24 & 13 \\
\cline { 2 - 4 } $\begin{array}{c}\text { for children with } \\
\text { disabilities }\end{array}$ & No & 156 & 87 \\
\cline { 2 - 4 } & $\begin{array}{c}\text { Sub } \\
\text { Total }\end{array}$ & 180 & 100 \\
\hline $\begin{array}{c}\text { Having special } \\
\text { training for inclusive } \\
\text { education/taking } \\
\text { training for children } \\
\text { with disabilities }\end{array}$ & Yes & 16 & 27 \\
\cline { 2 - 4 } & No & 44 & 73 \\
\hline
\end{tabular}

The above table demonstrates the lack of facilities for children with disabilities in schools. The targets of the educational reforms were to increase the enrollment of special or disadvantaged children but it is depended on the facilities provided to the children with special needs in schools. However, the data shows that there is a little opportunity remaining in schools because only 13 percent of children expose positive answer while $87 \%$ deny to have special facilities in their schools.

On the other hand, teachers' professional training is important indicator to nurture the special need children because training on inclusive education make teachers' teaching skill and develop new proficiency to take care of the children with disability. However, the findings reveal that only $27 \%$ of teachers found who participated in special training courses while $73 \%$ teachers have no training on inclusive education but dealings children with disabilities. The findings from FGD-3 depicts negative opinion about having necessary facilities for inclusive education. The result of this table is very alarming for equitable access of difficulty able child in classroom participation.

P4FGD3 said-

"I am from a reputed institution but it's not perfect for inclusive education. A little special care was taken for children with special needs. I did not find proper equipment for special learner. There was no braille system, and few hearing aids were allotted for leaner even though teachers were not fully prepared for giving special education. Some of the teachers possessed negative attitude towards special need children while some of them were very caring and well trained. Though our school have ramp, toilet and water facilities but I cannot consider my school as a child friendly compound fully."

Findings about Education Reforms

It is very positive that Bangladesh is a signatory country of all major international declarations related to inclusive education (IE). So, it has ratified policies and legislation in favour of IE. But, gradually recent literature suggests that having legitimized guidelines does not always ensure practices which are aligned with IE. The listed below tables explain the results focusing education reforms of secondary education in Bangladesh.

Table-7: Following Teachers' Guide in Regular Classroom

\begin{tabular}{|c|c|c|}
\hline Variables & $\mathrm{f}$ & $\%$ \\
\hline $\begin{array}{c}\text { Most of the } \\
\text { times }\end{array}$ & 36 & 60 \\
\hline Somewhat & 22 & 37 \\
\hline Never & 00 & 00 \\
\hline Infrequently & 02 & 03 \\
\hline Total & 60 & 100 \\
\hline
\end{tabular}

Table-7 presents positive results about using teachers' guide in classroom teaching-learning activities. All the teachers participated in this study answered of this item of questionnaire survey. According to the results, there are $60 \%$ teachers found who regularly follow teachers guide during teaching while $37 \%$ of the teachers 
sometimes follow the guide. On the other hand, there are a few teachers (3\%) found who rarely follow the teachers' guide. Same opinions also have been shared by the majority of the FGD participants.

Table 8. Student Centered Learning Environment

\begin{tabular}{|c|c|c|c|}
\hline \multicolumn{2}{|c|}{ Variables } & $\mathrm{f}$ & $\%$ \\
\hline $\begin{array}{c}\text { Having } \\
\text { student } \\
\text { center } \\
\text { learning } \\
\text { environment }\end{array}$ & Yes & 72 & 40 \\
\cline { 2 - 4 } & No & 108 & 60 \\
\cline { 2 - 4 } & Total & 180 & 100 \\
\hline
\end{tabular}

Student centered learning focus actively participation of students in the process which helps deepen learning. The table- 8 exhibits the status of student centered learning environment in school. There are $60 \%$ participants stated that they do not have student centered learning environment while $40 \%$ participants depict that they teach in the student friendly learning environment. FGD participants also have shared the same opinion. P4FGD2 stated-

"Our school environment is not student centered. We do not have sufficient learning materials in school. Our only school library is always locked. We also do not have much co-curricular activities in our school".

Table-9: Using Unified Curriculum Provided by NCTB
\begin{tabular}{|c|c|c|c|}
\hline \multicolumn{2}{|c|}{ Variables } & $\mathrm{f}$ & $\%$ \\
\hline Using unified & Yes & 60 & 100 \\
\cline { 2 - 4 } $\begin{array}{c}\text { curriculum } \\
\text { provided by } \\
\text { NCTB. }\end{array}$ & No & 00 & 00 \\
\cline { 2 - 4 } & Total & 60 & 100 \\
\hline
\end{tabular}

The results from above table expose that all teachers $(100 \%)$ use unified curriculum provided by NCTB which reflects positive image of textbook. P3FGD4 revealed-

"Our teachers follow unified and unitrack curriculum provided by NCTB, it is a great initiative to ensure educational reform. Student center learning environment is gradually increasing now a days, we have opportunity to participate more in our classroom by asking questions, doing presentation, using group discussion method etc."

Table-10: Level of Using ICT Materials and Creative Question
\begin{tabular}{|c|c|c|c|}
\hline \multicolumn{2}{|c|}{ Variables } & $\mathrm{f}$ & $\%$ \\
\cline { 2 - 5 } $\begin{array}{c}\text { Used ICT in } \\
\text { classroom } \\
\text { presentation } \\
\text { by teachers }\end{array}$ & Yes & 140 & 73 \\
\cline { 2 - 5 } & No & 40 & 22 \\
\hline \multirow{2}{*}{\begin{tabular}{c} 
Using \\
creative \\
questions \\
efficiently \\
for \\
\cline { 2 - 5 } \\
\cline { 2 - 5 } \\
assessment \\
by teachers
\end{tabular}} & Neutral & 180 & 100 \\
\cline { 2 - 5 } & Total & 180 & 100 \\
\hline
\end{tabular}

ICT is a very good component for quality education and our educational reforms emphasizes on ICT integration in classroom teaching-learning activities. Table-10 presents that the use of ICT in secondary school is in a decent situation because $73 \%$ of the students possess that the teachers present nicely ICT materials in classroom. In addition, exactly half of the students (50\%) illustrate that teachers efficiently use creative question in assessment system. In contrast, 39\% of students differently think about their teachers' and state that their teachers do not use creative question in assessment while $11 \%$ students are confused about what to say.

According to the opinion of P4FGD5 -

"The present condition of using ICT in classroom presentation is not bad, we have the facility of PowerPoint, every teachers has laptops and well trained for how to use multimedia classroom, but the internet service is not good. The level of using creative question is in medium level, teachers are trying to use more creative question in the examination but sometimes questions are too tough to write down."

Table-11: Using Effective Pedagogy and Interesting Teaching Learning Materials

\begin{tabular}{|c|c|c|}
\hline Variables & $\mathrm{f}$ & $\%$ \\
\hline
\end{tabular}




\begin{tabular}{|c|c|c|}
\hline $\begin{array}{c}\text { Most of the } \\
\text { times }\end{array}$ & 34 & 57 \\
\hline Sometimes & 26 & 43 \\
\hline Never & 00 & 00 \\
\hline Infrequently & 00 & 00 \\
\hline Total & 60 & 100 \\
\hline
\end{tabular}

Table-11 presents two common areas of educational reforms, which are indicators of inclusion to quality education. However, only $57 \%$ of teachers state that most of the times they use effective pedagogy and interesting teaching learning material while $43 \%$ sometimes use it. Actually, they are not confident about their teaching strategy according to the FGD results. They show different opinion from questionnaire survey in FGD, P2FGD6 illustrated-

"Our teachers are highly educated and qualified but I am afraid of their teaching skills, most of them have lack of required teaching skills and not being the facilitator. Our classroom is not the place of joyful learning. Our teacher's teaching learning materials are not as much interesting as the topics are".

From this FGD, it has been found that students are not fully satisfied with their classroom's environment. Many of the students thought that teachers could teach efficiently by receiving training on pedagogy while some of them differed and exposed that their teachers had good teaching skills and handle their classroom competently.

\section{Results and Discussions}

The collected data in this study reveal that gender equity and empty gender discrimination is found. It is also found an unpleasant proportion between student \& teacher ratio, and children with disabilities, ethnic minority against normal students' ratio in the classrooms. It is a light of hope that, now a day's the students are being admitted with different economic backgrounds, the schools are also welcoming them which is essential for ensuring inclusive education. Despite success, it is not expected level addressing the ratio of difficulty able child. However, the bitter truth is that, there is a lack of facilities for children with disabilities. Current educational reforms focus on enrollment of, but it can happen when the schools can efficiently provide the facilities for them. Unfortunately results illustrate that the schools have very little opportunity for special or disadvantaged children. Along with this, teachers are not fully prepared for giving quality and special education which is another threat for implementing inclusive education. Education reforms emphasize on teachers training, which is a must for achieving goals but the real scenario is not similar to policy and act. In contrast, the teachers have very positive attitude towards the practice of unified curriculum in schools. Similarly the use of ICT in secondary school is in a good situation. Making creative question is one of the most highly encouraging reforms in our country and whenever students take it positively it is an indicator of ensuring education reforms. Results also indicate that the teachers are unwilling to use teaching materials but it should be used regularly for making proper classrooms environment with appropriate pedagogy.

\section{Conclusion}

Over the last few years, Bangladesh has developed several national policy initiatives that can promote Inclusive Education (IE). The government has recognized IE as an approach to achieving the goals of Education for All (EFA). In the course of its inclusive reforms, it has developed some remarkable policy initiatives to promote IE in Bangladesh (Ahsan \& Mullik, 2013). However, the positive reflections of policy regarding the inclusion of children with disability also found in this study. Conversely, some results of this study require more attention to develop inclusive education in Bangladesh. However, it is expected that the findings of this study would influence policies for ensuring inclusive intervention of preparedness and rehabilitation. It will support the concerned development actors and planners to formulate need-based plan and implement appropriate programs for the mitigation of loss for the most vulnerable section of education

\section{References}

Ahmed, M., Sharma, U., \& Deppeler, J. (2012). Variables affecting teachers' attitudes towards inclusive education in Bangladesh. Journal of Research in Special Education Needs, 12(3), 132-140.

Ahsan, M. T., \& Burnip, L. (2007). Inclusive Education in Bangladesh. Australian Journal of Special 
Education, 31(1), 61-71.

Ahsan, M. T. (2013). National Baseline Study for "Developing a model of inclusive primary education in Bangladesh project" based on secondary Data. Dhaka: Plan Bangladesh.

Ahsan, M. T. \& Mullick, J. (2013). The journey towards inclusive education in Bangladesh: Lessons Learned. Prospects, 43(3), 151-164.

Ahsan, M. T., Sharma, U., Deepeler, J. (2012). Exploring pre-service teachers' perceieved teaching-efficacy, attitudes and concerns about inclusive education in Bangladesh. International Journal of Whole Schooling, 8(2), 1-20.

Al-Samarrai, S. (2007). Education spending and equity in Bangladesh. Working paper prepared for the 2007 Bangladesh poverty assessment, World Bank: 38. The World Bank: Dhaka.

Asian Development Bank. (2010). Gender equality results: Case studies- Bangladesh Teaching Quality Improvement (TQI) in Secondary Education. Philippines: Asian Development Bank.

Avramidis,E.,\&Norwich,B.(2002).Teachers' attitudes towards integration/inclusion: A review of the literature. Journal of Special Needs Education, 17(2), 129-147.

Campaign for Popular Education. (2005). Education Watch 2005: The State of Secondary Education Progress and Challenges. Retrieved April30,2008,from http://www.campebd.org/content/EW_2005.htm

Forlin, C., Loreman, T., Sharma, U., \& Earle, C. (2009). Demographic differences in changing preservice teachers' attitudes, sentiments and concerns about inclusive education. International Journal of Inclusive Education, 13(2), 195-209.

MoE. (2004). Bangladesh Moves Ahead.

MoE. (2010). The national education policy 2010. Dhaka: The Government of Bangladesh.

MoE. (2013). The proposed draft education act 2013. Dhaka: Law Cell, MOE.

MSW. (2013). Rights and Protection of the persons with Disability Welfare ACT, 2013.

UNESCO. (1994). Salamanca statement and framework for action on special education needs. Paris: UNESCO.

UNESCO. (2009). Inclusive education: The way of the future. Final report of the International Conference of Education (48th session). Paris: UNESCO. 